\title{
NANOSTRUCTURED PHOTOSENSITIZER BASED ON A TETRACATIONIC DERIVATIVE OF BACTERIOCHLORIN FOR ANTIBACTERIAL PHOTODYNAMIC THERAPY
}

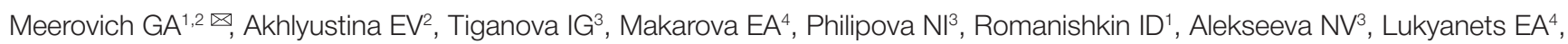
Romanova YuM ${ }^{3}$, Loschenov VB ${ }^{1,2}$

${ }^{1}$ Prokhorov General Physics Institute of the Russian Academy of Sciences, Moscow

${ }^{2}$ Institute of engineering physics for biomedicine, National Research Nuclear University "MEPHI", Moscow

${ }^{3}$ Gamaleya National Research Center of Epidemiology and Microbiology, Moscow

${ }^{4}$ Organic Intermediates and Dyes Institute, Moscow

\begin{abstract}
Making antibacterial PDT more effective is a task that calls for the development of photosensitizers (PS) based on polycationic synthetic bacteriochlorins and subsequent analysis of properties of such photosensitizers. This study aimed to explore photophysical and antibacterial properties of the nanostructured PS based on $3-\mathrm{Py}_{4} \mathrm{BSHp}_{4} \mathrm{Br}_{4}$, tetracationic amphiphilic derivative of synthetic bacteriochlorin. The PS was solubilized in a $4 \%$ Kolliphor ELP to obtain its nanostructured dispersion. We researched the absorption and fluorescence spectra intensity and profiles, studying concentrations from 0.001 to $0.2 \mathrm{mM}$, and found that the aggregation level of the PS in question is low throughout the range investigated while the S. aureus (gram-positive) and P. aeruginosa and K. pneumoniae (gram-negative) PD inactivation effectiveness is high.
\end{abstract}

Keywords: photosensitizer, cationic bacteriochlorin, aggregation, nanostructured dispersion, fluorescence, antibacterial photodynamic therapy

$\triangle$ Correspondence should be addressed: Gennady A. Meerovich

Vavilova 38, Moscow, 119991; meerovich@mail.ru

Received: 31.08.2018 Accepted: 27.09.2018

DOI: $10.24075 /$ brsmu.2018.087

\section{НАНОСТРУКТУРИРОВАННЫЙ ФОТОСЕНСИБИЛИЗАТОР НА ОСНОВЕ ТЕТРАКАТИОННОГО ПРОИЗВОДНОГО БАКТЕРИОХЛОРИНА ДЛЯ АНТИБАКТЕРИАЛЬНОЙ ФОТОДИНАМИЧЕСКОЙ ТЕРАПИИ}

\author{
Г. А. Меерович $1,2 \bowtie$, Е. В. Ахлюстина ${ }^{2}$, И. Г. Тиганова ${ }^{3}$, Е. А. Макарова ${ }^{4}$, Н. И. Филипова ${ }^{3}$, И. Д. Романишкин $^{1}$ \\ Н. В. Алексеева ${ }^{3}$, Е. А. Лукьянец ${ }^{4}$, Ю. М. Романова ${ }^{3}$, В. Б. Лощенов ${ }^{1,2}$ \\ Институт общей физики имени А. М. Прохорова РАН, Москва \\ ${ }^{2}$ Инженерно-физический институт биомедицины, Национальный исследовательский ядерный университет «МИФИ», Москва \\ ${ }^{3}$ Национальный исследовательский центр эпидемиологии и микробиологии имени Н. Ф. Гамалеи, Москва \\ ${ }^{4}$ Научно-исследовательский институт органических полупродуктов и красителей, Москва
}

\begin{abstract}
Задача повышения эффективности антибактериальной ФДТ делает актуальными создание и исследование фотосенсибилизаторов (ФС) на основе поликатионных синтетических бактериохлоринов. Целью работы было изучить в широком диапазоне концентраций фотофизические и антибактериальные свойства наноструктурированного ФС на основе тетракатионного амфифильного производного синтетического бактериохлорина $3-\mathrm{Py}_{4} \mathrm{BCH}_{4} \mathrm{Br}_{4}$. Наноструктурированную дисперсию ФС получили путем его солюбилизации в 4\%-м Kolliphor ELP. Исследование интенсивности и формы спектров поглощения и фрлуоресценции в диапазоне концентраций от 0,001 до 0,2 мМ продемонстрировало низкую агрегацию этого ФС во всем диапазоне и высокую эффективность фотодинамической инактивации грамположительных бактерий S. aureus и грамотрицательных бактерий P. aeruginosa и K. pneumoniae.
\end{abstract}

Ключевые слова: фотосенсибилизатор, катионный бактериохлорин, агрегация, наноструктурированная дисперсия, фрлуоресценция, антибактериальная фотодинамическая терапия

$\varangle$ Для корреспонденции: Геннадий Александрович Меерович ул. Вавилова, д. 38, г. Москва, 119991; meerovich@mail.ru

Статья получена: 31.08.2018 Статья принята к печати: 27.09.2018

DOI: $10.24075 /$ vrgmu.2018.087

Antibacterial photodynamic therapy (APDT) is a promising mode of treatment of localized infection sites: surgical and burn wounds, trophic and diabetic ulcers, etc [1, 2]. Unlike antibiotic therapy, APDT destroys cells of bacteria without promoting their resistance to the treatment [3-6]. Most pathogens, including antibiotic-resistant strains of bacteria, are susceptible to APDT [7].

Localized infection sites, infected wounds in particular, most often contain Staphylococcus aureus (S. aureus) Gram- positive bacteria, Pseudomonas aeruginosa ( $P$. aeruginosa) and Klebsiella pneumoniae (K. pneumoniae) Gram-negative bacteria, the strains of which may be resistant to many types of antibiotics, cause chronic infections and various dangerous consequences for the patients [8].

Gram-positive and Gram-negative bacteria are fundamentally different in their structure and sensitivity to drug exposure. The cell wall of Gram-positive bacteria is just a minor obstacle for most photosensitizers (PS). In Gram-negative bacteria, it 
has an additional structural element, a 10-15 nm thick outer membrane, which is heterogeneous and consists of porin proteins, lipopolysaccharide trimers and lipoproteins that build an external pseudo-surface of densely packed negative charges [9-11]. Such a system prevents the humoral protective factors from penetrating and enables resistance to many drugs: only relatively hydrophilic compounds with a molecular weight below 700 Da diffuse through the porin channels, and as the size and weight of the molecules grow, the probability of their diffusion into Gram-negative bacteria decreases. Only cationic PSs effectively interact with Gram-negative bacteria [10, 11]. Cationic PS have another advantage: their highly concentrated aqueous compositions (solutions or nanodispersions) can be used for sensitization, since the Coulomb repulsion of molecules of cationic bacteriochlorins negatively affects their aggregation [12] and thus improves the efficacy of the photodynamic processes.

While selecting PS for APDT, it is necessary to take in account that some bacteria, e.g., P. aeruginosa, can infect the tissue up to the depth of 12-15 mm [13], which renders conventional antibacterial agents (solutions, ointments, gels) and PSs phototoxic only when excited with visible range light ineffective. Therefore, proper photodynamic treatment of such infected sites requires PSs excited by the light in near infrared spectral range, at the wavelengths of $720-850 \mathrm{~nm}$, which cover the "biological tissue transparency window". In this connection, derivatives of cationic bacteriochlorins are being actively investigated for their potential to be PS in APDT. A number of studies are dedicated to researching the properties of polycationic derivatives of synthetic bacteriochlorins with a molecular weight of 1500-1800 Da; according to their results, such PSs are capable of inactivating both Grampositive S. aureus bacteria and Gram-negative P. aeruginosa bacteria, but the minimum bactericidal concentrations of such photosensitizers are quite high (> $6 \mu \mathrm{M}$ for $S$. aureus and about $25 \mu \mathrm{M}$ for $P$. aeruginosa) [14].

Increasing the efficacy of APDT is a problem that requires development of PSs based on polycationic synthetic bacteriochlorins having smaller molecular size and mass. This study is aimed at exploring photophysical and antibacterial properties of the nanostructured PSs based on 3-Py $\mathrm{BCHp}_{4} \mathrm{Br}_{4}$, tetracationic amphiphilic derivative of synthetic bacteriochlorin meso-tetra-(1 heptyl-3-pyridyl)-bacteriochlorin tetrabromide.

\section{METHODS}

Compared to a derivative described in an earlier study [14], tetracathionic amphiphilic derivative of synthetic bacteriochlorin meso-tetra-(1-heptyl-3-pyridyl)-bacteriochlorin tetrabromide $3-\mathrm{Py}_{4} \mathrm{BCHp} \mathrm{Br}_{4}$, is less lipophilic and has the molecule of a smaller radius. The derivative was synthesized by mesotetra-(3-pyridyl)-bacteriochlorin alkylation with heptyl bromide in nitromethane in an inert atmosphere. The nanostructured dispersion of $3-\mathrm{Py}_{4} \mathrm{BCHp} \mathrm{Br}_{4}$ was obtained through its solubilization in 4\% Kolliphor ELP (BASF; Germany). Measurements taken with Zetasizer Nano Series ZS 3600 (Malvern Panalitical; UK) put the hydrodynamic size of nanoparticles within 12-14 nm.

We used Hitachi U-3410 dual-beam spectrophotometer (Hitachi; Japan) to study PS absorption in the concentration range of 0.001-0.1 mM and LESA-01-Biospec spectrum analyzer (BIOSPEC; Russia) to study the spectral-fluorescent properties. $532 \mathrm{~nm}$ laser was used to excite the fluorescence; this wavelength belongs to the bacteriochlorin derivative's Q2 band. To study the features of the spectral band shape we investigated spectral-fluorescent properties of the PS in cuvettes of various lengths ( $1 \mathrm{~mm}$ and $10 \mathrm{~mm}$ ) and normalized its fluorescence spectral intensity to the fluorescence band maximum (reduced spectral maximum to 1). Thus, when analyzing the spectra, we could separate changes associated with reabsorption from those resulting from aggregation.

To measure the luminescence lifetime of aqueous compositions of the studied PSs, we used a time-resolved spectrometer. The spectrometer consisted of Picosecond Light Pulser PLP-10 (Hamamatsu; Japan), a fiber output pulse laser emitting $65 \mathrm{ps}$ pulses at $637 \mathrm{~nm}$; Jarrell-Ash fiber input polychromator (Division of Fisher Co; USA); Semrock LD01785/10-12.5 optical filter (Semrock Inc; USA) at the input, which filtered out light outside of the bacteriochlorin derivatives luminescence band and minimized background noise. The resulting signal was approximated by the sum of several exponentials.

We used S. aureus 15, P. aeruginosa 32, K. pneumoniae 1556 clinical isolates to study the process of photoinactivation of planktonic bacteria. The bacteria were grown in LB nutrient broth or on 1\% LB agar (Difco; USA). To determine the minimal bactericidal concentration (MBC) of PS applicable to plankton cultures, we incubated them with PS for 30 minutes and irradiated at the light energy density of $20 \mathrm{~J} / \mathrm{cm}^{2}$ (standard conditions). The initial titer of bacteria was $1 \cdot 10^{8} \mathrm{CFU} / \mathrm{ml}$ (Colony Forming Units per $\mathrm{ml}$ ). The PS dilution pattern was double, starting at $1 \mathrm{mM}$. After incubation, the bacterial suspension was centrifuged for $5 \mathrm{~min}$ at $7000 \mathrm{rpm}$ in the Eppendorf laboratory centrifuge (Eppendorf; Germany), PS removed, bacteria resuspended in saline; then the suspensions of each concentration, as well as the PS-free control samples, were poured into wells of the two 96-well flat-bottomed plates, $100 \mu \mathrm{l}$ in each well. One plate was used for the irradiation experiment, the other served as a dark control.

SFD-M-760 LED source (ANO MIKEL; Russia) emitting at $760 \mathrm{~nm}$ (wavelength at maximum) and $35 \mathrm{~nm}$ FWHM was used for irradiation purposes. The power density was $22-25 \mathrm{~mW} / \mathrm{cm}^{2}$; irradiation lasted for 20 minutes. To control the power density, we used Coherent labmax (Coherent; USA) diaphragm laser power meter.

After irradiation, $50 \mu \mathrm{l}$ of suspension from each well were added to LB agar Petri dishes, then incubated in the dark at $37^{\circ} \mathrm{C}$ for $20 \mathrm{~h}$. Examining the dishes, we looked for the samples that gave no growth, registered the corresponding PS concentrations and took the smallest of them as MBC.

\section{RESULTS}

By studying the dependence of $3-\mathrm{Py}_{4} \mathrm{BCHp} \mathrm{Br}_{4}$ absorption on its concentration in the nanodispersion, we aimed to evaluate the severity of the aggregation process. The operating absorption band of $3-\mathrm{Py}_{4} \mathrm{BCHp}_{4} \mathrm{Br}_{4}$ has a narrow spectral contour; its FWHM is about $22 \mathrm{~nm}$, maximum at approximately $760 \mathrm{~nm}$. According to the research, in contrast to polycationic phthalocyanines, there are no expressed signs of aggregation in the absorption spectra of the $3-\mathrm{Py}_{4} \mathrm{BCHp} \mathrm{Br}_{4}$ dispersion [15]: the shape of the absorption spectrum does not change as the concentration grows; the dependence of optical density on molar concentration is linear (Bouguer law satisfied) and consistent with the extinction values determined at low concentrations (Fig. 1).

To confirm the assumption that the studied PS shows low aggregation capabilities, we studied the spectral-fluorescent properties of its nanodispersion, focusing on the shape and intensity of fluorescence spectra, as well as radiative lifetime of the excited $3-\mathrm{Py}_{4} \mathrm{BCHp} \mathrm{Br}_{4}$ at high and low concentrations. 
The analysis of the PS fluorescence spectra shows that increasing the cuvette length from 1 to $10 \mathrm{~mm}$ at low $(0.005 \mathrm{mM})$ concentrations does not affect the shape of the spectral contour (Fig. 2, spectra 1, 2) and leads only to an insignificant $(0.3 \mathrm{~nm})$ shift of the spectrum maximum due to reabsorption. The fluorescence band remains narrow $(27 \mathrm{~nm})$.

At high $(0.05 \mathrm{mM})$ concentrations that approximately correspond to the PS concentrations in blood plasma 1 hour after intravenous administration, reabsorption causes a long wavelength shift of the fluorescence band spectrum maximum that depends on the length of the cuvette: $1.5 \mathrm{~nm}$ in the cuvette $1 \mathrm{~mm}$ long, $3.4 \mathrm{~nm}$ - in a cuvette $10 \mathrm{~mm}$ long. The half-width of the fluorescence band also grows (by $1.1 \mathrm{~nm}$ in a $1 \mathrm{~mm}$ cuvette, by $4.3 \mathrm{~nm}$ in a $10 \mathrm{~mm}$ cuvette), but the shape of the spectral contour does not change, no additional bathochromically and hypsochromically shifted peaks appear there.

Studying the radiative lifetime with the help of the approach described earlier [16], we discovered two components. In water-based experiments, the dominant component has the average lifetime of 2.8 ns; its share is approximately $86 \%$. In

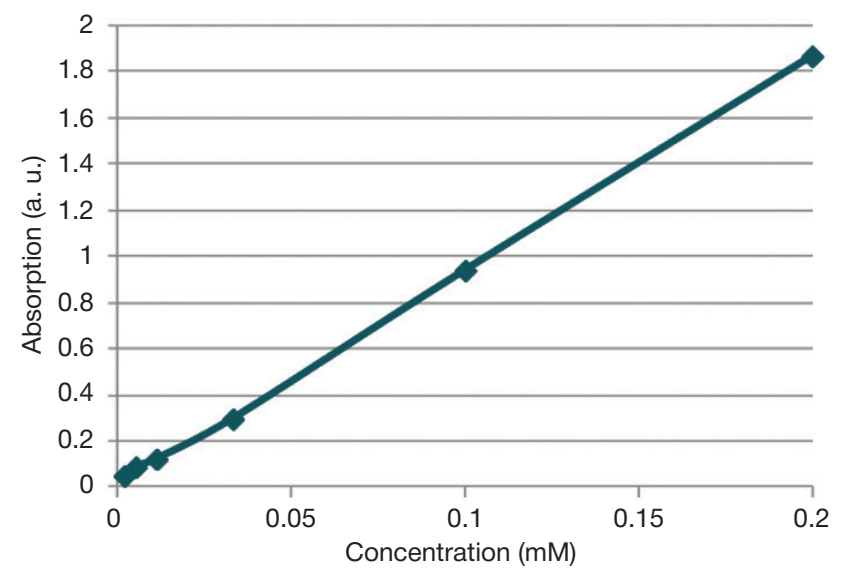

Fig. 1. Dependence of $4 \%$ Kolliphor ELP $3-\mathrm{Py}_{4} \mathrm{BCHp}_{4} \mathrm{Br}_{4}$ dispersion absorption on its concentration

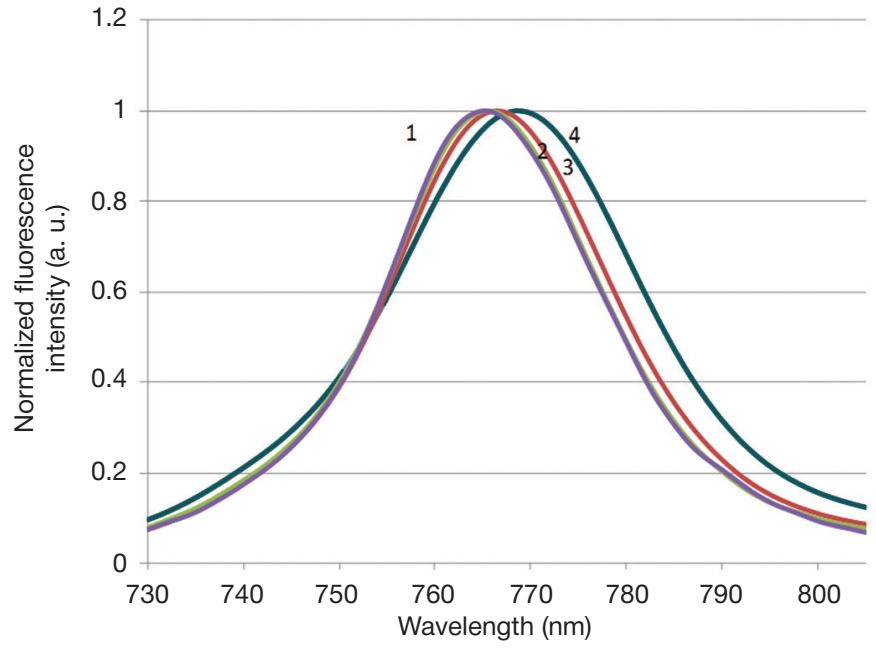

Fig. 2. Normalized fluorescence spectra of $3-\mathrm{Py}_{4} \mathrm{BCHp}_{4} \mathrm{Br}_{4}$ dispersions, various concentrations (spectra 1, $2-0.005 \mathrm{mM}$; spectra $3,4-0.05 \mathrm{mM}$ ) and lengths of cuvettes (spectra 1, 3-1 mm; spectra 2, 4-10 mm)

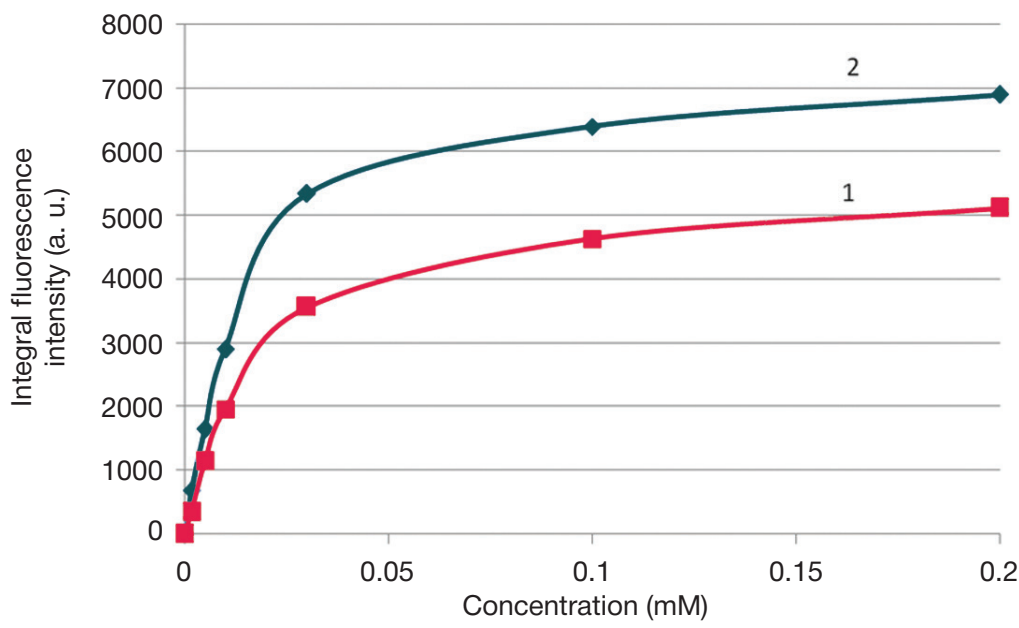

Fig. 3. Dependence of integral fluorescence intensity of 3- $\mathrm{Py}_{4} \mathrm{BCHp} \mathrm{Br}_{4}$ aqueous compositions on their molar concentration: 1 - in water; 2 - in blood plasma 
experiments with blood plasma, where aggregation is reduced, the dominant component has the average lifetime of about $2.9 \mathrm{~ns}$, and its share is almost $100 \%$.

The dependence of dispersion's integral fluorescence intensity on PS concentration is close to being linear up to $0.03 \mathrm{mM}$ (Fig. 3); at higher concentrations, it becomes sublinear. The dependence pattern is the same for the $3-\mathrm{Py}_{4} \mathrm{BCHp}_{4} \mathrm{Br}_{4}$ composition in blood plasma. Furthermore, the shape of the curves remains almost unchanged, although the fluorescence intensity in blood plasma is 1.3-1.4 times higher than that in water.

Table below contains the discovered MBCs of $3-\mathrm{Py}_{4} \mathrm{BCHp} \mathrm{Br}_{4}$ at standard conditions

\section{DISCUSSION}

Investigating absorption of the studied PS, we found that its aggregation values are low in the considered range of concentrations [15], shape and half-width of the absorption band spectrum therein do not change, and the absorption itself linearly depends on the concentration.

Analysis of the fluorescence band shape changes associated with increased concentrations and cuvette lengths allows an assumption that the main reason behind the phenomenon observed at higher concentrations of the researched PS is reabsorption, and contribution of aggregation, which also occurs, is insignificant. This is also backed by the investigation of radiative lifetime of the excited PS based on
3- $\mathrm{Py}_{4} \mathrm{BCHp}_{4} \mathrm{Br}_{4}$ and dependence of the fluorescence intensity on concentration of $3-\mathrm{Py}_{4} \mathrm{BCHp}_{4} \mathrm{Br}_{4}$ in dispersion, especially in blood plasma [17-21].

These data lead to a conclusion that the efficacy of photodynamic processes at high concentrations of $3-\mathrm{Py}_{4} \mathrm{BCHp}_{4} \mathrm{Br}_{4}$ will not deteriorate, which allows using $3-\mathrm{Py}_{4} \mathrm{BCH} \mathrm{P}_{4} \mathrm{Br}_{4}$ nanodispersions of such concentrations as sensitizers in APDT.

Compared to the previously described PSs based on cationic bacteriochlorins [14], 3- $\mathrm{Py}_{4} \mathrm{BCHp}_{4} \mathrm{Br}_{4}$ offers significantly lower MBC values for Gram-positive S. aureus bacteria and Gram-negative P. aeruginosa bacteria in plankton state. The MBC for Gram-negative K. pneumoniae bacteria are also low.

\section{CONCLUSIONS}

The results of the research show that tetracationic PS based on the synthetic amphiphilic derivative of $3-\mathrm{Py}_{4} \mathrm{BCHp}_{4} \mathrm{Br}_{4}$ bacteriochlorin, the molecular size and weight of which are smaller, can photodynamically inactivate Gram-positive S. aureus, Gram-negative $P$. aeruginosa and $K$. pneumoniae bacteria. Investigation of photophysical properties of the PS in a wide range of concentrations revealed its low aggregation capability in water and blood plasma. The studies conducted allow a conclusion that the PS based on a nanostructured $3-\mathrm{Py}_{4} \mathrm{BCHp}_{4} \mathrm{Br}_{4}$ is promising as a component of protocols of photodynamic treatment of localized infections by Grampositive and Gram-negative bacteria.

Table. 3- $\mathrm{Py}_{4} \mathrm{BCHp}_{4} \mathrm{Br}_{4} \mathrm{MBC}$ values, standard conditions (incubation time $0.5 \mathrm{~h}$, exposure dose $20 \mathrm{~J} / \mathrm{cm}^{2}$ )

\begin{tabular}{|c|c|c|c|}
\hline Bacteria & S. aureus & P. aeruginosa & K. pneumoniae \\
\hline MBC, $\mu \mathrm{M}$ & 0.2 & 6.2 & 3.1 \\
\hline
\end{tabular}

\section{References}

1. Park YS, Lee HB, Chin S et al. Acquisition of extensive drug resistant Pseudomonas aeruginosa among hospitalized patients: risk factors and resistance mechanisms to carbapenems. Hosp Infect. 2011; 79 (1): 54-8. DOI: 10.1016/j.jhin.2011.05.014.

2. Bertoloni G, Rossi F, Valduga G, Jori et al. Photosensitising activity of water- and lipid-soluble phthalocyanines on prokaryotic and eukaryotic microbial cells. Microbios. 1992; 71 (286): 33-46.

3. Nakonieczna J, Michta E, Rybicka M et al. Superoxide dismutase is upregulated in Staphylococcus aureus following protoporphyrin-mediated photodynamic inactivation and does not directly influence the response to photodynamic treatment. BMC Microbiol. 2010; (10): 323. https://DOl.org/10.1186/14712180-10-323.

4. Tavares A, Carvalho CMB, Faustino MA et al. Antimicrobial photodynamic therapy: study of bacterial recovery viability and potential development of resistance after treatment. Marine Drugs. 2010; 8 (1): 91-105. DOI: 10.3390/md8010091.

5. Hamblin MR, Hasan T. Photodynamic therapy: a new antimicrobial approach to infectious disease. Photochem Photobiol Sci. 2004; 3 (5): 436-50.

6. Vera DM, Haynes $\mathrm{MH}$, Ball $\mathrm{AR}$ et al. Strategies to potentiate antimicrobial photoinactivation by overcoming resistant phenotypes. Photochem Photobiol. 2012; 88 (3): 499-511. DOl: 10.1111/j.1751-1097.2012.01087.x.

7. Maisch T. Resistance in antimicrobial photodynamic inactivation of bacteria. Photochem Photobiol. 2015; 14 (8): 1518-26. DOI: 10.1039/c5pp00037h

8. Almeida A, Cunha A, Faustino MAF et al. Porphyrins as antimicrobial photosensitizing agents. In: Photodynamic Inactivation of Microbial Pathogens: Medical and Environmental
Applications. Hamblin MR, Jori G, editors. London: RSC Publishing, 2011; p. 83-160.

9. Wainwright M. Photodynamic antimicrobial chemotherapy. Antimicrob Chemother. 1998; 42 (1): 13-28.

10. Friedrich CL, Moyles D, Beveridge TJ, Hancock RE. Antibacterial action of structurally diverse cationic peptides on Gram-positive bacteria. Antimicrob Agents Chemother. 2000; 44 (8): 2086-92.

11. Nikaido H. Prevention of drug access to bacterial targets: Permeability barrier and active efflux. Science. 1994; 264 (5157): 382-8.

12. Moan J. Photochemistry and Photobiology. The photochemical yield of singlet oxygen from porphyrins in different states of aggregation. 1984; (39): 445-9. Available from: https://DOI. org/10.1111/j.1751-1097.1984.tb03873.x.

13. Bjarnsholt Th, Jensen $\mathrm{PO}$, Moser $\mathrm{C}$, Hoiby N. Biofilm infections. Heidelberg: Springer, 2011

14. Tiganova IG, Makarova EA, Meerovich GA, Alekseeva NV Tolordava ER, Zhizhimova YS et al. Photodynamic inactivation of pathogenic bacteria in biofilms using new synthetic bacteriochlorin derivatives. Biomedical Photonics. 2017; 6 (4): 27-36. Russian. Available from: https://DOl.org/10.24931/2413-9432-2017-6-4-27-36.

15. Makarov DA, Kuznetsova NA, Yuzhakova OA, Savina LP, Kaliya OL, Lukyanets EA et al. Effects of the degree of substitution on the physicochemical properties and photodynamic activity of zinc and aluminum phthalocyanine polycations. Russian Journal of Physical Chemistry A. 2009; 83 (6): 1044-50.

16. Bystrov FG, Makarov VI, Pominova DV, Ryabova AV, Loschenov VB. Analysis of photoluminescence decay kinetics of aluminum phthalocyanine nanoparticles interacting with immune cells. Biomedical Photonics. 2016; 5 (1): 3-8. Russian. Available from: https://DOl.org/10.24931/2413-9432-2016-5-1-3-8. 
17. Juzenas P, Juzeniene A, Rotomskis R, Moan J. Spectroscopic evidence of monomeric aluminium phthalocyanine tetrasulphonate in aqueous solutions. Journal of Photochemistry and Photobiology B: Biology. 2004; 75 (1-2): 107-10. DOI: 10.1016/j.jphotobiol. 2004.05.011.

18. Dhami S, Phillips D. Comparison of the photophysics of an aggregating and non-aggregating aluminium phthalocyanine system incorporated into unilamellar vesicles. Journal of Photochemistry and Photobiology A: Chemistry. 1996; 100 (1-3): 77-84.

19. Reddi E, Jori G. Reviews of Chemical Intermediates. 1988; (10):
241-68. Available from: https://DOl.org/10.1007/BF03155995.

20. Tominaga $T T$, Yusbmanov VE, Borissevitch IE, Imasato $H$, Tabak M. Aggregation phenomena in the complexes of iron tetraphenylporphine sulfonate with bovine serum albumin. Journal of Inorganic Biochemistry. 1997; (65): 235-44.

21. Changenet-Barret P, Gustavsson T, Markovitsi D, Manet I, Monti S. Unravelling molecular mechanisms in the fluorescence spectra of doxorubicin in aqueous solution by femtosecond fluorescence spectroscopy. Physical Chemistry Chemical Physics. 2013; 15 (8): 2937-44.

\section{Литература}

1. Park YS, Lee HB, Chin S et al. Acquisition of extensive drugresistant Pseudomonas aeruginosa among hospitalized patients: risk factors and resistance mechanisms to carbapenems. Hosp Infect. 2011; 79 (1): 54-8. DOl: 10.1016/j.jhin.2011.05.014.

2. Bertoloni G, Rossi F, Valduga G, Jori et al. Photosensitising activity of water- and lipid-soluble phthalocyanines on prokaryotic and eukaryotic microbial cells. Microbios. 1992; 71 (286): 33-46.

3. Nakonieczna J, Michta E, Rybicka $M$ et al. Superoxide dismutase is upregulated in Staphylococcus aureus following protoporphyrin-mediated photodynamic inactivation and does not directly influence the response to photodynamic treatment. BMC Microbiol. 2010; (10): 323. https://DOI.org/10.1186/14712180-10-323.

4. Tavares A, Carvalho CMB, Faustino MA et al. Antimicrobial photodynamic therapy: study of bacterial recovery viability and potential development of resistance after treatment. Marine Drugs. 2010; 8 (1): 91-105. DOI: 10.3390/md8010091.

5. Hamblin MR, Hasan T. Photodynamic therapy: a new antimicrobial approach to infectious disease. Photochem Photobiol Sci. 2004; 3 (5): 436-50

6. Vera DM, Haynes $\mathrm{MH}$, Ball $\mathrm{AR}$ et al. Strategies to potentiate antimicrobial photoinactivation by overcoming resistant phenotypes. Photochem Photobiol. 2012; 88 (3): 499-511. DOI: 10.1111/j.1751-1097.2012.01087.x.

7. Maisch T. Resistance in antimicrobial photodynamic inactivation of bacteria. Photochem Photobiol. 2015; 14 (8): 1518-26. DOl: 10.1039/c5pp00037h

8. Almeida A, Cunha A, Faustino MAF et al. Porphyrins as antimicrobial photosensitizing agents. In: Photodynamic Inactivation of Microbial Pathogens: Medical and Environmental Applications. Hamblin MR, Jori G, editors. London: RSC Publishing, 2011; p. 83-160.

9. Wainwright M. Photodynamic antimicrobial chemotherapy. Antimicrob Chemother. 1998; 42 (1): 13-28.

10. Friedrich CL, Moyles D, Beveridge TJ, Hancock RE. Antibacterial action of structurally diverse cationic peptides on Gram-positive bacteria. Antimicrob Agents Chemother. 2000; 44 (8): 2086-92.

11. Nikaido $\mathrm{H}$. Prevention of drug access to bacterial targets: Permeability barrier and active efflux. Science. 1994; 264 (5157): 382-8.

12. Moan J. Photochemistry and Photobiology. The photochemical yield of singlet oxygen from porphyrins in different states of aggregation. 1984; (39): 445-9. Available from: https://DOI. org/10.1111/j.1751-1097.1984.tb03873.x.

13. Bjarnsholt Th, Jensen PO, Moser C, Hoiby N. Biofilm infections. Heidelberg: Springer, 2011

14. Тиганова И. Г., Макарова Е. А., Меерович Г. А., Алексеева Н. В., Толордава Э. Р., Жижимова Ю. С. и др. Фотодинамическая инактивация патогенных бактерий в биопленках с использованием новых синтетических производных бактериохлорина. Biomedical Photonics. 2017; 6 (4): 27-36. Доступно по ссылке: https://DOl.org/10.24931/2413-94322017-6-4-27-36.

15. Макаров Д. А., Кузнецова Н. А., Южакова О. А., Савина Л. П., Калия О. Л., Лукьянец Е. А. и др. Поликатионные фталоцианины цинка и алюминия: синтез, влияние степени замещения на физико-химические свойства и фотодинамическую активность в водной среде. Журнал физической химии. 2009; 83 (6): 1183-90.

16. Быстров Ф. Г., Макаров В. И., Поминова Д. В., Рябова А. В., Лощенов В. Б. Исследование кинетики затухания фотолюминесценции молекулярных нанокристаллов фталоцианина алюминия при взаимодействии с иммунокомпетентными клетками. Biomedical Photonics. 2016; 5 (1): 3-8. Доступно по ссылке: https://DOl.org/10.24931/24139432-2016-5-1-3-8.

17. Juzenas $\mathrm{P}$, Juzeniene A, Rotomskis R, Moan J. Spectroscopic evidence of monomeric aluminium phthalocyanine tetrasulphonate in aqueous solutions. Journal of Photochemistry and Photobiology B: Biology. 2004; 75 (1-2): 107-10. DOI: 10.1016/j.jphotobiol. 2004.05.011

18. Dhami S, Phillips D. Comparison of the photophysics of an aggregating and non-aggregating aluminium phthalocyanine system incorporated into unilamellar vesicles. Journal of Photochemistry and Photobiology A: Chemistry. 1996; 100 (1-3): 77-84.

19. Reddi E, Jori G. Reviews of Chemical Intermediates. 1988; (10): 241-68. Available from: https://DOl.org/10.1007/BF03155995.

20. Tominaga $\Pi$, Yusbmanov VE, Borissevitch IE, Imasato $H$, Tabak M. Aggregation phenomena in the complexes of iron tetraphenylporphine sulfonate with bovine serum albumin. Journal of Inorganic Biochemistry. 1997; (65): 235-44.

21. Changenet-Barret P, Gustavsson T, Markovitsi D, Manet I, Monti S. Unravelling molecular mechanisms in the fluorescence spectra of doxorubicin in aqueous solution by femtosecond fluorescence spectroscopy. Physical Chemistry Chemical Physics. 2013; 15 (8): $2937-44$ 